\title{
LEGAL CARE AND FRICTION IN FAMILY DETENTION
}

\section{ERIN ROUTON \\ Cornell University}

(D) https:// orcid.org/0000-0002-4719-1401

From across the desk in the cold, private room of the detention facility, the mother handed me a worn piece of paper with a number scribbled across. I dialed it and waited to hear the call go through before handing the receiver back to her. She smiled broadly at me as she told her sister that she and her daughter were getting released soon. I sat quietly on the opposite side, waiting to answer questions she might have about the process of getting out: who would buy her bus tickets to her new home, when officials would make the call to her family to make travel arrangements, and so on. She worried that her family would not have enough money to buy the expensive tickets, so we placed multiple calls to different contacts. Her daughter, who was around four years old and had previously been sitting patiently next to her mother, disappeared from view behind the desk.

Suddenly, I felt a soft brushing against my suede shoes. I looked down and saw a petite hand gently petting my foot. As her mother explained the situation to another family friend, I knelt down on the floor, gasping with faux surprise as I met her daughter's eyes. She giggled loudly and pulled her hand away before crawling out from under the desk and ambling over to my side. She clearly preferred to play rather than sit quietly while her mother spoke on the phone, and yet, as usual, this space offered no toys. She and I spoke quietly as we examined 
the only object beyond the phone in the barren room: the desk. She was pulling at cords and empty drawers when she then became fixated on one of the small holes in the corner of the desk, partially covered by removable plastic pieces. She frantically tried to pull the pieces out, looking down inside the crevices. I looked too to find the source of her interest: she had spied one of the most precious forms of "contraband" in the detention center: crayons. I lifted the edges of the coverings as she reached in and pulled out each lovely color one by one, smiling with delight at her discovery. As her mother finished her calls, her daughter quietly completed a drawing. Afterward, I stuffed these implements back into their hiding place for the next distracted child and burdened mother that would inevitably walk through those doors. The mother and I hugged before leaving the privacy of the room. She smiled, thanked me for helping her, and I waved goodbye to her daughter as she left with her artwork cradled under arm.

In recent years, the detention of migrant families in the United States, and the often associated practice of family separation, have become increasingly familiar topics to many Americans. Yet an understanding of the everyday realizations of these policies, practices, and spaces remain, to a great extent, elusive. This is, of course, no accident: migration scholars have noted the complex productions of isolation and dislocation involved in migrant detention (e.g., Mountz 2012; Martin 2015; Loyd and Mountz 2018). This article concerns itself with illuminating a particular aspect of migrant incarceration within the context of so-called family detention or residential centers in the United States. My research focuses on the centrality of care in the labors, experiences, and particular social arrangements involving legal advocates providing pro bono aid to the asylum-seeking families held in these facilities.

Scholarship on the subject of care has a long, cross-disciplinary history, stirring important debates and new forms of social recognition. Marjorie Murray et al. (2017) contend that anthropological research on care, despite recently having expanded to studies of everyday encounters "beyond the clinical," has historically centered on the fields of health care. Care, of course, has long existed in the studies and debates of feminist anthropologists and sociologists, science and technology researchers, and scholars broadly associated with the study of work, some of which have looked precisely at the clinical, others beyond it, examining the various forms of relationality and interaction that intimately involve care (e.g., Hochschild 1983; Tronto 1993; Boris and Parreñas 2010; Garcia 2010; Mol, Moser, and Pols 2010; Puig de la Bellacasa 2017). Nevertheless, such research has rarely directly considered the relationship between care and the work of lawyers and other legal prac- 
titioners. This article aims to apply the insights of this expansive and diverse research on care and care work to legal advocacy. In doing so, my argument aims to extend scholarship that recognizes caregivers by valuing the myriad services that advocates provide detainees as not just forms of legal aid but also as care work.

I argue that care is analytically useful for understanding legal advocacy and the relationships in which legal advocates engage in these spaces. To start, legal assistance is commonly interpreted as a unidirectional, often unsentimental encounter for those providing the assistance; scholars remind us of the many ways in which legal education itself often encourages a "casting aside" of personal emotions or empathy in favor of supposed neutrality and legal authority (Scheingold and Sarat 2004; Mertz 2007). Of course, legal anthropologists and migration scholars have repeatedly demonstrated the extent to which legal encounters, especially those involving refugee or otherwise migratory groups, are fraught with emotions that engage all associated parties (e.g., Coutin 2000, 2016; Cabot 2013). My research affirms and builds on this insight. What I observed during fieldwork with legal advocates indicated an expansive form of assistance, attention, and relationality, far exceeding the limitations of legal aid and refuting a perception of their work as unidirectionally affective. As I observed them, what advocates did and the ways in which they articulated their roles led me, in a sense, to care. Advocates showed deep involvement in emotion work and multidirectional affective exchanges that informed their own intimate subjectivities. Care moved through the ways in which they practiced legal advocacy, tended to detainees and each other, managed their relationships with administrators, and even played an important role in conflicts, some of which I will explore here.

Thus, this article illustrates why care matters not only to the ways in which we can understand these spaces and the work of legal advocates but also to how it brings into focus certain relational and institutional complexities and conflicts. I suggest a term - legal care — as a way to approach such forms of labor and relational encounters. While not a novel concept in and of itself, legal care offers a conceptual pathway to recognizing the work of legal advocates and aid workers as care work without disavowing the central role that the law plays within these contexts. It is, at its core, an extension of care into the legal practical terrain. Much cross-disciplinary scholarship has explored legal work with asylum applicants and immigrants (e.g., James and Killick 2012; Eagly and Shafer 2015; Ryo 2018), as well as with lawyers and paralegals, as ethnographic subjects (e.g., Henderson 1987; Pierce 1995). While researchers have also devoted attention to lawyers and legal practitioners as advocates and activists (e.g., Abel 1995; Sarat and Scheingold 2005; 
Merry 2006), this linkage demands greater attention, particularly in today's political climate and related responses from advocacy communities. Legal practitioners, professional or otherwise, rarely receive consideration as caregivers, and yet as I demonstrate in this article, they often practice care to intimate and complex degrees.

Of course, to recognize the caregiving efforts of legal advocates, we must first recognize the violence with which advocates and detainees contend in these spaces, indeed, the violence engrained within multiple facets of family detention. The following sections will explore the different ways in which violence takes shape in these facilities, from so-called family detention, itself a destructively misleading concept, to everyday barriers to legal information and representation, to poor physical and mental health care. Legal advocates are implicated both directly and indirectly in the harmful practices which define these spaces, often compelled to struggle against forces beyond their control or influence and far beyond the apparent boundaries of legal aid. Yet advocates' expressions and sentiments of care also serve as vehicles for resistance against the practical and institutional forms of violence family detention inflicts.

It is crucial to note that the encounters between legal advocates and incarcerated parents and children in family detention are, due to the environment's nature, fleeting. This will become clear as my argument unfolds. While I suggest that legal care has potentially important implications for legal encounters beyond the context I discuss here, this transitory quality of the relationships defines the kind of care possible in these spaces. This care is not defined by prolonged engagements, intimacies that naturally unfold over time, or the kinds of clearly bounded giver-receiver roles one might find in other caregiving environments. The fleeting nature of these encounters simultaneously shapes the care given and informs the conflicts with which legal advocates contend. Thus, legal care in family detention is construed through its conflicts, and its frictions. "Friction reminds us," Anna Lowenhaupt Tsing $(2005,5)$ claims, "that heterogeneous and unequal encounters can lead to new arrangements of culture and power." Using legal care, I hope to explore the kinds of configurations of power, relationality, and resistance that are borne out of the everyday frictions that define spaces such as these.

As a final introductory note, I want to clarify the critical time period in which this research took place. The ethnographic detail that informs this article's arguments about legal care comes from a time in the field when the Obama administration had effectively reinstituted the incarceration of asylum-seeking migrant families. Thus, while I bore witness to Trump administration changes in 
legal policies and practices that dramatically impacted the institution and everyday realities of family detention, what I present in this article effectively preceded those changes. This is a critical distinction not only because it draws attention to the harm both administrations have inflicted on asylum-seeking families but also because it highlights the adaptability of legal advocates engaged in forms of caring resistance as they navigate a rapidly shifting asylum landscape. The degree of violence inflicted on asylum seekers by the Trump administration far exceeded that of the preceding one; I certainly do not dispute this fact here. Nevertheless, it was and will continue to be critically important to recognize the history of both harm and care within family detention.
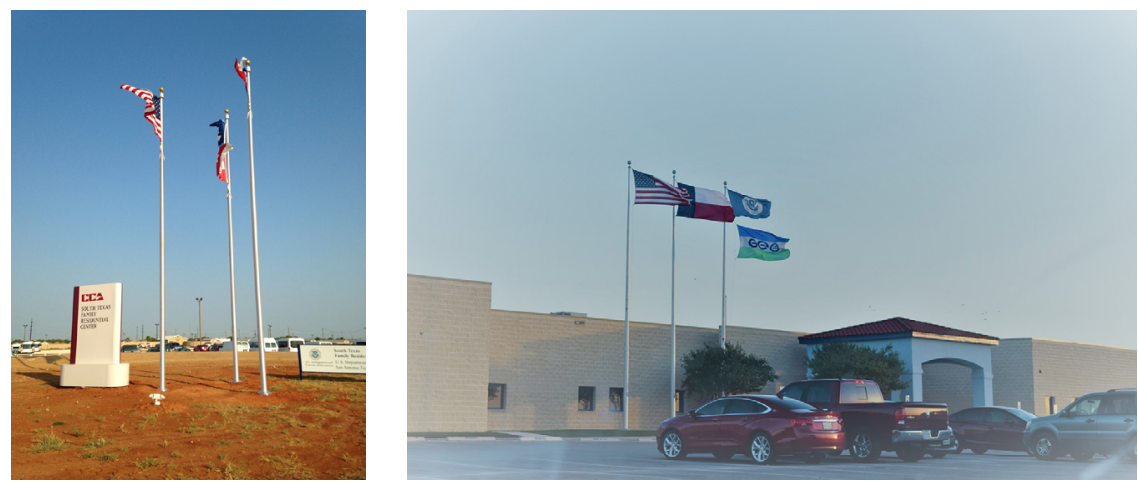

Figure 1.The South Texas Family Residential Center, left, and the Karnes County Residential Center, right. Photos by Erin Routon.

\section{ORIENTATION}

In late 2014, standing against the backdrop of a clear, bright sky, and flanked by officers and American flags, then secretary of homeland security Jeh Johnson told the crowd of reporters: "Frankly, we want to send a message that our border is not open to illegal migration, and that if you come here, you should not expect to be simply released" (Preston 2014). Johnson's symbolic message referred to the facility still under construction behind him: The South Texas Family Residential Center. This center, located in Dilley, Texas, would become one of three family detention centers in the United States. The ethnographic research presented here comes from my time spent at this facility and the Karnes County Residential Center, located in Karnes City, Texas, over an extended research period from 2016 to 2017. I will hereafter refer to these centers as simply Dilley and Karnes. 
With a capacity for 2,400 detainees - rivaling the population of the town and eclipsing the capacity of the neighboring prison (see Texas Department of Criminal Justice n.d.) — Dilley stands as the largest immigrant detention center in the United States, contractually owned and managed by CoreCivic, formerly the Corrections Corporation of America. In fact, both facilities under discussion here are owned and managed by private prison corporations. The GEO Group, another of the world's largest such corporations, operates Karnes. The facilities opened as a response to a "surge" earlier in 2014 of tens of thousands of asylum-seeking families, or "family units," in the government's language, arriving at the MexicoUnited States border, principally from the Northern Triangle countries of Honduras, El Salvador, and Guatemala. The vast majority of those arriving sought asylum in the United States as a result of increasing gang violence, police and government collusion with gangs, and the inability to receive local protection against domestic or intimate partner violence.

While the government refers to these centers as "residential family" facilities, in reality they have housed almost exclusively single mothers and their minor children. By historically excluding fathers and other family relations, these centers have effectively engaged in family separation since they opened. In this way, the very notion of family separation, even as it relates to the limited context of the detention of asylum-seekers, preceded what the public has recently come to know under that term. While the Trump administration instituted new policies related to the administration's so-called zero-tolerance measures that indeed expanded the physical splitting of family members and familial relations through novel tactics, the government's practice of family separation itself is not new.

As family detention centers, these facilities effectively function as punitive processing centers for asylum-seekers placed into "expedited removal" legal proceedings. Created by the Illegal Immigration Reform and Immigrant Responsibility Act of 1996 (IIRIRA), expedited removal describes a truncated legal process in which particular immigration officers are given authority to make decisions on migrants' legal cases, potentially denying them the opportunity of having a regular immigration court hearing (American Immigration Council 2019). The mothers and children who end up in these facilities after arriving at different U.S. border points - either at official ports of entry or at other locations at or near the border - and request asylum, are to all apparent accounts arbitrarily selected for placement in this legal category, which requires them to undergo a part of the asylum process while in detention. The latter is known as the "credible fear" or "reasonable fear" interview. ${ }^{1}$ Only by passing, or receiving a positive decision in, 
this interview - one in which they must demonstrate both their credibility and how their experiences make them eligible for asylum - are they released into the interior United States, continuing the rest of the lengthy legal process outside of detention. Otherwise, they eventually face deportation from the facility.

Another migratory group has resided in these facilities since their inception: pro bono legal advocates. These advocates have shown up daily to provide free legal aid to all those detained. In Dilley, these advocates form part of a nonprofit project now known as Proyecto Dilley. Karnes is served by a group of legal advocates associated with a Texas-based organization known as RAICES. Both groups function in similar ways and often collaborate. Advocates with these groups contend that the practice of family detention constitutes an unnecessary, cruel, and unusual form of treatment of asylum-seeking parents and children and, knowing the complexities inherent in navigating the asylum process, have committed to the universal representation of all detainees while simultaneously litigating for the closure of these facilities. Thus, unlike in most immigration defense settings, all detainees have the option of detailed, individual assistance, regardless of the purported merits of their case. This is critical for several reasons, not least because most applicants cannot afford legal representation or assistance with their cases, since private attorneys are usually prohibitively expensive and are mostly located in faraway cities. Without the help of volunteer legal advocates, the detainees would have little hope of assistance with their cases while locked away in remote locations. The advocates' presence also proves critical because it is so difficult to "pass" a credible or reasonable fear interview without previous access to legal advice. While the Trump administration has effected numerous changes to asylum law that have negatively impacted the likelihood of success for applicants, my observations of this process during the Obama administration - which oversaw the opening of these facilities - demonstrated the previous difficulty of passing this interview without legal support. The interview itself was and continues to be fraught with issues, from translation inadequacies to procedural failures to outright subversive, antagonistic behavior on the part of some asylum officials. Thus preparation and continued legal assistance remain of vital importance.

Both legal-aid projects comprised a small number of paid staff and temporary volunteers. Although staff members remained with their projects for months or years, both projects heavily relied on volunteer labor. In fact, non-local volunteers did the majority of the daily work in detention. These migratory volunteers had received training from project staff members on the ground, typically serving the projects for a week before being replaced with a new group of volunteers. 
The volunteers ranged in associations and experience with the law and legal practice. Some were lawyers or law students, others doctors or social workers, while still others came to perform the critical role of interpreters. Some had experience working or volunteering with asylum cases, while others knew very little about the subject. The organizations generally welcomed all who were interested in helping, regardless of their expertise, but they simultaneously emphasized the need for particular skills, primarily language or legal experience. I volunteered with each of these organizations, performing the same daily tasks alongside other staff and volunteers in both of these facilities each week throughout my extended fieldwork.

Each week in "baby jail” (as advocates called it) clients' cases would get passed along to a new group via a vast online case-management system. These projects depend heavily on such forms of collective action: not only do advocates rely on the work of previous volunteers, but in daily practice, they also depend on one another to manage difficult cases and overcome the myriad bureaucratic or legalistic roadblocks that arise, sharing different skills. The members' exceedingly diverse backgrounds and expertise make the projects dependent not only on collective action but also on collective knowledges, for example about asylum and immigration law, responses to trauma survivors, and approaches to working with children. While advocates often work with clients individually, some collaboration with others almost always occurs in the background.

Time limits in family detention significantly strained advocates' work, playing a major role in the frenetic, often crisis-like environment of the center. A particular court decision, known as the Flores Settlement Agreement, ultimately made the case that children could be held in detention, but only for brief periods of time. In 2015, in District Court Judge Dolly Gee's ruling on the agreement's terms, children were to be released "without necessary delay" (Preston 2014). This came to be interpreted as not longer than twenty days. ${ }^{2}$ This arbitrary deadline made processes move at a rapid pace in detention, meaning that advocates had little time to prepare their clients for critical moments or to respond to deportation attempts. Furthermore, because the majority of applicants' cases fell under the category of asylum law, understood as persecution based on "membership within a particular social group (PSG)" — a category characterized by vague and unpredictable boundaries - advocates typically needed even more time with clients to construct a strong case. The rapid pace of the work environment resulted in fleeting encounters of care rather than prolonged engagements.

These advocates did not seek to help detainees "win” an asylum case. Some volunteers, who were professional lawyers, were capable of continuing the legal 
representation of clients after their release; some elected to do so. Yet these advocates primarily fought to get their "clients" out of detention, so they could reunite with family, friends, and services, and have the opportunity to properly prepare their asylum claim or pursue another form of relevant legal status. While advocates performed many different tasks in detention, arguably the most critical was to prepare clients for their fear interview, so that they could receive the passing decision that would allow their release. Thus, the majority of the work revolved around this interview: preparing clients for success and then responding when some clients inevitably did not pass. Advocates repeatedly demonstrated the value of these forms of preparation for the outcome of fear interviews. In what is known as the "prep" conversation, an advocate speaks privately with an individual about their case, helping them shape their legal claims ahead of the interview with the asylum officer. Prior to this individualized conversation, advocates conduct informational group sessions, known as charlas, or chats, in which they offer detailed explanations and answer questions about aspects of asylum law and the processes clients face. Detainees did not have effective access to this information from the government or facility contractors; few even understood where they were or how they had ended up there, much less what the asylum process entailed. Some did not encounter anyone who spoke their language until they met with these advocates, who used their collective resources to locate remote interpreters. The effort of advocates' work derives from a need to prepare clients to achieve a sort of legal consciousness (Merry 1990) for their fear interview, in which they are required to articulate their case in terms meaningful to asylum officers, without the aid of legal translators (Cunningham 1992) or expert witnesses (Good 2006). While these legal projects collectively represented their detained clients, advocates could not officially speak on their behalf in interviews or in court proceedings taking place in the facility, thus necessitating quick work that made clients understand the expectations set on them.

\section{INTERFERENCE}

Legal advocates in family detention are child caregivers. Figure 2 depicts gifts, remnants of encounters between child detainees and an advocate, after she sat with them at tables and desks or sprawled out on tile floors. Together, they colored and waited for the children's mothers to finish discussing their cases with advocates in private rooms. While mothers wiped away tears with the edge of their government-issued T-shirts, talking about la violación, the unreasonable impuesto de guerra they owed "MS" (MS-13), or even the lies la migra told them, their 


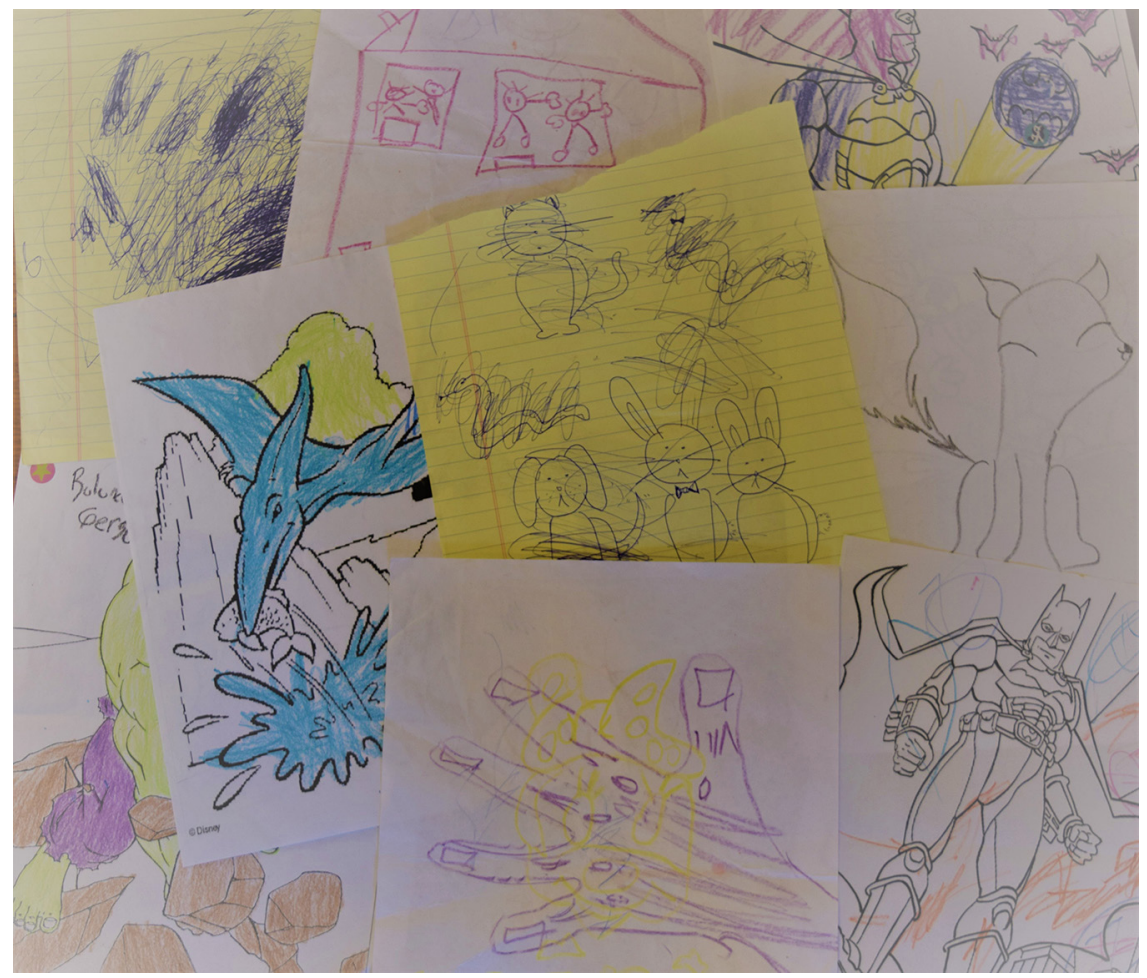

Figure 2. Drawings made by child detainees at Dilley and Karnes. Photo by Erin Routon.

babies would sit at a table, talking about their pets from home, asking which colors they should use for the Hulk's pants, and wondering if the advocate could draw them a cat (and subsequently name it). Far from simple colored drawings made to pass the time, the children's images are tangible expressions of quiet distraction, of attention to something at least remotely pleasurable in places that are objectively not, and of care in contested terrain.

Young children in these facilities needed sources of entertainment and distraction while their mothers worked on their cases - sometimes for hours- discussing intimate details many did not want their children to hear. These conversations took place in private rooms, primarily for purposes of confidentiality and comfort. Both inside and out of these private rooms, in the open area of the visitation buildings, crayons and paper became critical tools. If children resisted separation from their mothers, they could be given these to play with in the room, so that they wouldn't be listening in or distracting her from speaking. If the mother needed them to be outside of the room, other advocates could sit with them while they colored. Crayons and coloring books provided an excellent option for work 
with children due to their mobility in the space and the attentiveness involved in playing with them.

From the facilities' earliest days, administrators had instituted various rules about crayons and coloring books. The outlines of these rules changed frequently, and, understanding the greater importance of the crayons, advocates consistently pushed back against them. In November 2016, administrative officials banned crayons at the Karnes facility, at least within the facility's visitation area (Laughland 2016), where legal advocates met with mothers and young children. It was not the first time that such items had been prohibited at a family detention center. In 2014, an incident known as "crayon-gate" had occurred at a temporary family detention facility in Artesia, New Mexico. Advocates at Dilley were also often met with barriers in attempting to bring in crayons or coloring books. At Karnes, Immigration and Customs Enforcement (ICE) claimed that the ban had resulted from "an action resulting from crayons which RAICES staff/volunteers [had] given children which [had] caused property damage to the contractor." In other words, a child had colored on a table in the open space of the legal visitation area. Advocates of both projects responded quickly, releasing statements to the media about the ban, posting on social media, forming petitions, and tweeting about the incident to Crayola, cheekily asking for instructions on how to clean crayon marks. In a release, advocates argued not only that "such markings are a cost that comes with the detention of children" but also that "it is extremely disturbing that ICE's concern for GEO's property takes precedence over the well-being of the children and their mothers' rights to legal advice" (RAICES T. n.d.). As this statement illustrates, the uproar from advocates did not simply result from the apparent absurdity of the ban. The latter also impacted advocates' abilities to give care and mothers' abilities to obtain legal assistance, because it took away options that allowed mothers to speak comfortably about their cases and thus receive the sort of attention they needed.

In this incident, advocates were the intended recipients of punishment. By explicitly naming RAICES as the supposed instigator of the event that "destroyed" property, administrators laid bare their intentions: children coloring on tables did not cause damaged property; advocates giving them crayons did. This incident, and the language used to describe it, demonstrates a critical argument in my research: administrators deployed punitive strategies against advocates in both overt and covert ways. The friction between these groups inspired different responses to what was ultimately an irreparable conflict, as their distinct efforts appeared to exist 
at counter purposes. Yet despite this conflict, both administrators and advocates deployed care as a central force in their strategies and tactics.

Mere weeks after the crayon ban, I walked into the legal visitation area to find a large chalkboard installed, an apparent response to advocates' fierce and ultimately viral pushback. Many advocates wondered how facility administrators had still missed the point behind their frustration. The chalkboard, like the facility's toys, remained firmly outside of the private spaces in which parents met with advocates, where things like crayons proved the most useful. Months after the installation of this large chalkboard, I walked with a client into one of the private rooms and saw newly mounted miniature chalkboards. Neither chalkboard ever had chalk; that was kept at the guard's station. Children were usually too anxious around the guards to ask for the chalk themselves, and thus the boards remained perpetually blank.

Superficially, the addition of chalkboards was a material expression of care by facility administrators. This act, though, did not resolve the problem that the ban had created, and it did not assuage the friction between advocates and administrators. The chalkboards were not an equal replacement for crayons and coloring books; they did not meet the needs of the children. As a result, advocates believed, as they did in many other scenarios of conflict, that administrative responses after the fact were committed in the interest of maintaining a positive self-image, rather than in that of actual care for the well-being of their detainees. Clients' well-being was connected to their ability to receive legal assistance, functionally impeded by not being able to separate children from their parents for brief periods.

This broad point of conflict, in which material objects meant to benefit the work of advocates became "contraband," manifested itself at various times throughout my research. It is possible to interpret these refusals as forms of punishment for advocates, as many did, as well as an expression of the state's power and authority to control and police the activities of both detained children and their parents. These often overlapped in detention. In other scenarios, administrative punitive measures appeared to more overtly correspond with efforts to interfere with the work of advocates, sometimes painfully so.

\section{PROXIMITY}

Contrary to Michel Foucault's (1977) broad assessment of the historical trajectory of the prison as by-and-large a shift away from bodily punishment, Didier Fassin (2016) contends that significant degrees of punitive work on bodies have not left carceral spaces. While not often explicitly considered official elements of 
punishment, persistently poor health care and unmitigated sexual assault make for just a couple of the ways in which prisoners are subjected to forms of this bodywork. With respect to both of these, a disregard of care for the body is bound up with the status of imprisonment. Because care work requires bodily as well as emotional proximity (Alber and Drotbohm 2015), giving care to incarcerated individuals becomes complicated by these normative punitive strategies, especially in places such as family detention facilities, which, while reproducing punitive strategies familiar to other carceral environments, nonetheless attempt to maintain a caring identity. In the cases studied here, legal advocates became entwined in these processes; they were not only involved in counteracting harmful body-work - at times, through the critical application of nonverbal practices of care (Mol, Moser, and Pols 2010) — but could also be unwittingly subjected to punitive strategies themselves.

Maria, $^{3}$ a mother from Haiti, was seemingly on the verge of a panic attack. Sitting in the plastic chair in the nearly empty room, she began hyperventilating. The stress of recent developments with her case seemed too overwhelming, and her future appeared ever more hopeless. She had received a negative decision during her interview, meaning that the officer did not find her claim credible. In subsequent appeals, the judge had affirmed the officer's decision; Maria was, therefore, left with few options before the initiation of deportation proceedings. Alejandro, a staff member of the legal project at Dilley, was seated on the opposite side of the table, watching her anxiety swirl like a dust storm. He then did what he felt she needed: He swiftly walked to her side of the table, sat next to her, and placed his hand on her shoulder while speaking softly to calm her.

After a brief period, the dust cleared just enough, and they carried on talking about the next steps for her case. Not many days after that, Alejandro walked in as usual on a Monday morning to start work with a group of new volunteers and was casually handed a piece of paper by facility staff in the security building. The letter communicated that he had been banned from the facility. Unlike the many volunteers and staff that passed through the facility, he would never enter that space again. All this because he had touched the client he was working with, and an employee of the facility saw it happen. Facility administrators decided that this gesture constituted a threat to detainees and banned him in the interest of their care.

This event demonstrates the unpredictable practical applications of security in detention (Hall 2012). It was followed by intense litigation on behalf of the legal project attempting to reverse the decision to revoke Alejandro's access permis- 
sions. The experience proved incredibly difficult for him to process. Simultaneously abrupt and drawn out, he had to wait for at least a month in relative silence from administrators and his own project team to learn that the legal challenges would remain unsuccessful. He felt hurt, angry, and guilty for leaving the few remaining staff members to manage the immense workload inside without him. He was sad that he did not get to say goodbye to his clients and that he would not get to meet and help the new clients arriving every day. When we met up at a taco shop in San Antonio months later, he said he was still trying to reckon with the fact that he would not be coming back. It turned out that this ban had been expanded to prohibit him from entering all other detention spaces managed by CoreCivic, which meant that what he had hoped would become a career of helping detainees with the language and legal skills he had built would be seriously limited.

This incident led to what advocates came to call the ban on hugging. This forced change in behavior proved difficult for many to accept, as the development of intimate relationships were a constant in advocate-client interactions. Clients often reached out to hug advocates, forcing advocates to move their own bodies away. Some advocates considered this a hurtful gesture, difficult to explain to clients and denying them their right to a typical yet meaningful human exchange. Some would speak about how they would quickly jerk their bodies backward if they saw a client reaching out to hug them within view of security cameras and guards. Others chose to reject the rule and embraced clients in those moments of intimacy that called for it, awaiting potential repercussions that, inexplicably, never seemed to arrive. Still others would argue that it happened too quickly, that they did not have time to communicate to the other person before they were embraced by them, but that they did not try to stop it from happening.

Angela was a long-term volunteer, staying on with the Dilley project for weeks or months at a time. She was an undergraduate student and gifted cellist from Juárez, Mexico. She became a favorite among many clients, more than a few of whom treated her like a daughter, some even trying to set her up on dates with their non-detained sons. Her warmth and closeness with clients produced a natural intimacy, and as might be expected, frequently led to moments in which clients attempted to embrace her. Sometimes she let it happen; in others, when in view of guards, she would try to avoid it. She told me:

There was this one mom I worked with . . she had been raped when she was little and was bullied and abused by different people throughout her life because of it. When her husband found out that she had been raped, he beat 
her and said that she should have told him about it. That he wouldn't have been with her. So, I went with her to her interview, and it was a really hard interview. Afterwards, we walked out together, and she said to me "thank you, you've been more to me than my own family, you've done more than my family has ever done for me. You take care of me." Then she just fell into my arms. Like, I know they can't give us hugs, but when someone falls into your arms, you can't do shit. They just fall apart in your arms. So, I was holding her, and there were so many guards around us. She was just crying on me, and I cried too.

In a way, Angela's story speaks poetically to what advocates do and how they interpret their practices. This is not an ideal caregiving situation. Advocates and detainees are relative strangers, and advocates both recognize and struggle with this fact. They meet briefly before having to manifest some sense of trust and comfort in order to exchange necessary care. Because the trauma experienced by detainees, which led them to leave their homes, is compounded by the harm created by the carceral environment, caregiving sometimes looks less like an intimate embrace and more like someone keeping someone else's body from falling to the ground.

As these experiences illustrate, advocates are subjected to their own form of punitive body-work. Their care is constrained by the facility's purported interest in the well-being of detainees. Physical contact is prohibited because it is framed as a threat to the imprisoned body. Though not made explicit by administrative entities or these legal projects, the source of this punitive action likely relates to one of the regulations concerning physical abuse in carceral spaces. In 2014, the Department of Homeland Security released a regulation - known as the Prison Rape Elimination Act (PREA) — that, coupled with ICE's policy known as the Sexual Assault and Abuse Prevention and Intervention, was meant to expand oversight of physical abuse concerns in migrant detention facilities (see ICE n.d.). While my research did not find evidence that this indeed constituted the justification administrative officials used to not only ban Alejandro but also to then justify new practices denying advocates and detainees the right to hug one another, I suggest this was a possible legal justification. It is purely conjecture on my part, but conjecture influenced by conversations had with legal advocates over time. ${ }^{4}$ Regardless of official intentions or stated justifications, in this particular case, a hug, as an expression of intimacy, is important for the caring relationality between advocates and their clients. Denying them this appears part of an extensive punitive strategy aimed at the advocates themselves, which advocates then interpret as harmful 
to themselves and detainees. Yet in this instance, administrators' actions are not promoted as punishment against advocates, but are rather justified through care for detainees. Yet these supposedly caring actions ultimately deprived detainees of the sort of care they themselves sought in their interactions, and that advocates desired to provide for them.

The troubled feelings of care that advocates experienced in response to being denied a small but important element of relationality with their clients illustrates the necessity of recognizing care as practice and acknowledging the ways in which we imagine or think through care (Puig de la Bellacasa 2017). Facility administrators' actions align with what Miriam Ticktin $(2011,5)$ calls the "antipolitics" of care, in which "brutal measures may accompany actions in the name of care and rescue . . . [and] ultimately work to reinforce an oppressive order." Other scholars have charted how violence may be evoked by acts intended as care, sometimes through expressions of indifference or uncare (Gupta 2012; Mulla 2014). So, too, a regulation to police sexual assault that punishes advocates who hug their distressed clients. These incidents demonstrate how, in situations in which multiple actors participate with care, everyday practices contest what counts as care or harm. Care, here, is not a solid object with clearly defined boundaries. It is best understood in this exchange not as a moral good but as something interpreted and entangled within the discourses surrounding its use. The very way in which advocates find themselves in caring exchanges, in this case through physical proximity, becomes the site on which administrators build a counternarrative, thus denying meaningful contact. The hugging ban thus lends evidence to the frictions between regimes of rights-based processes_-determined by administrative officials and carceral regulations - and legal advocates' caregiving. The apparently arbitrary application of such rules, of course, belies legitimate concerns for the care of detainees and reinforces perceptions of punishments borne out of those, and other, frictions between parties seemingly serving cross-purposes.

\section{CARE IN CONFLICT}

While care often breaches categorical boundaries (Alber and Drotbohm 2015), it might be broadly understood as something involving both practical and sentimental, or affective, elements. Care is simultaneously done, thought, and felt. Starting with Joan C. Tronto and Berenice Fisher's broad definition of care as "everything that we do to maintain, continue, and repair 'our world' so that we can live in it as well as possible" (Tronto 1993, 103), my analysis also aligns with scholarly views of care that emphasize its embodied, situated, and contingent 
qualities (e.g., Hamington 2004; Puig de la Bellacasa 2017) and caring practices as characterized, in part, by their relationality and interdependency (e.g., Kittay and Feder 2002; Cooper 2018) and fantastical or "imaginal” potentialities (Hunleth 2019). Annemarie Mol, Ingunn Moser, and Jeannette Pols's (2010) articulation of care, which involves "tinkering" on uncertain grounds and living with "the erratic" - emphasizing unpredictability as well as a commitment to continuous engagement - is instructive for making sense of the emergent and urgent environs of family detention and legal advocates' necessarily experimental tinkerings.

Such perceptions of care offer important visibility to the multilayered landscape of legal advocacy in a context where the facility administration's claims to care paradoxically proscribe and delimit much care practice. These are, after all, "residential centers," not, as one facility employee in particular liked to aggressively remind advocates, "prisons." Indeed, on CoreCivic's website, officials offer the following description for the Dilley facility: "Employing several hundred individuals, this center's mission is to provide an open, safe environment with residential housing as well as educational opportunities for women and children who are awaiting their due process before immigration courts" (CoreCivic n.d.). The carefully crafted language is clearly intended to distance the company from any appearance of incarceration or punishment. Facility employees reinforce this position through daily practices, for instance, by insisting that they be referred to as "residential supervisors" rather than "guards."

How does thinking through or with care (Puig de la Bellacasa 2012) aid in making sense of the conflicts that come to define everyday encounters in these spaces? The most common manifestation of conflict is found in contentious encounters between advocates and administrative actors, from guards to ICE officers, asylum officers, and immigration judges. Cheryl Mattingly (2010) refers to these kinds of encounters as "borderland moments." The detention center makes for a kind of borderland in multiple respects: detainees await determination on whether or not they will be allowed beyond the second, sometimes third or fourth, set of barriers intended to keep out those subjects deemed foreign. But they constitute borderlands in other senses as well. In her study of clinical borderlands, Mattingly argues that borders can also designate spaces defined by particular practices that cohere individuals or groups who otherwise would not be. As a result, in such zones, she argues, actors constantly question the actions of others and struggle to understand one another.

In her research on intimate partner visitation in prisons, Megan Comfort (2008) demonstrated that an inherent conflict exists between those tasked with 
the micro details of daily control and management, like guards or other associated officials, and the resistance naturally effected by free persons traversing this same terrain in carceral facilities. Within family detention facilities, border frictions between advocates and administrative officials take multiple, often quite distinct, forms, while also expressing shared qualities. Beliefs about what is good, necessary, or harmful for detainees are contested by advocates, administrators, and detainees themselves, and these frictions play a substantive role in advocates' perceptions of and feelings about the detention environment. Simultaneously, the practical movement of advocates' work with detainees is determined by administrators' and advocates' relationships with them. To give care to detained clients, in other words, advocates depend on a degree of collaboration with administrators. Thus my research examines not only the tensions between advocates and administrators but also the distinct care given to those relationships.

The metaphor of friction appears, again, particularly suited for understanding the sorts of encounters and relationships borne out of legal care work in this environment. The ways in which advocates and their work grate against administrative processes and officials in these facilities is palpable every day, as evidenced in the aforementioned incidences. The use of punishment as an expression of power (Foucault 1977) and control is not simply limited to incarcerated persons but extends to those who care for them. Setting aside for the moment questions about globalization, I follow Tsing (2005) in my consideration of how the boundaries of care within this particular borderland must be reimagined and perhaps reconstituted in light of these frictions.

\section{LEGAL CARE}

In describing the collaborative history of the Dilley project's approach to such work, their now defunct website once claimed: "This concept of what some called 'lawyer camp' captured the hearts and minds of willing volunteers. Rather than just taking over a paper file handed to them, they were taking over the legal care of a human being desperately needing their help." ${ }^{5}$ The phrase legal care rarely came into use on the ground. While I independently came to see the advocates' work as akin to care, after encountering this language on the site, I wondered what might in fact constitute legal care. My conceptual use of this phrase owes much intellectually to the anthropological and feminist theorizations of care already cited. Legal care draws attention to the ways in which legal practitioners perform as caregivers. In this formulation of care work, the law sits in a central position. It is the mechanism that brings about the need for care, as it is used to in- 


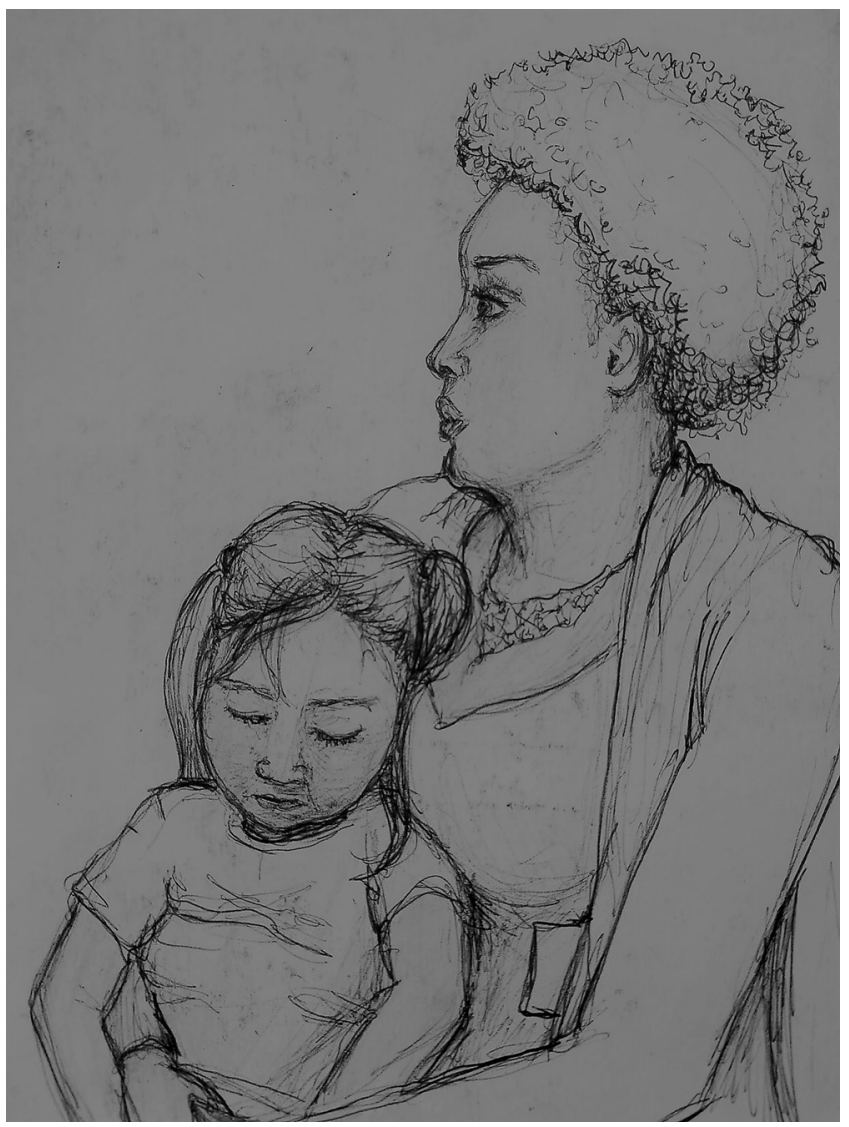

Figure 3. As photographs are not allowed inside these facilities, advocates make drawings that depict inner workings. Here, a depiction of an advocate caring for a detained child while her mother works on her case with another advocate.

Drawn by volunteer and artist Molly McGowan.

carcerate and isolate those seeking a form of protected status in the United States. However, it is also the mechanism that brings those needing care in detention into contact with those positioned in some way to assist with its provision. As I have shown, the law was simultaneously used as a tool for the provision and the denial of care. In this setting, the law_-as practiced and struggled with daily-becomes knowable (Mountz 2010) through its relationship to care.

María Puig de la Bellacasa $(2017,8)$ encourages becoming "involved with care as a living terrain that [needs] to be constantly reclaimed from idealized meanings, from the constructed evidence that, for instance, associates care with a form of unmediated work of love accomplished by idealized carers." Legal advocacy in family detention should by no means be interpreted as an "unmediated 
work of love," and legal practitioners, especially lawyers, are often far from the ideal of a caregiving subjectivity. This is not to say that loving sentiments do not play a significant role in how these advocates interpret their experiences; they often do. Many spoke about feelings akin to love that they felt for the relative strangers with whom they worked. The intensity of these fleeting encounters irrefutably shaped the production of these sentiments. It is also not to say that many legal practitioners, even lawyers, do not possess or project idealized caregiving qualities. What this research demonstrates, though, is a reclamation of care not delimited by either of these. In feeling terms, care is as much characterized by anger and sadness in this environment as it is by love or joy. Similarly, caregivers negotiate conflicted interests in their daily work, and embody seemingly contradictory subjectivities.

The marginalization of care (Lawson 2007) — the unrecognition of the ways in which care is both denied to some while affording others significant privileges speaks to the need for greater attention to the subject in different environments and spheres of relationality. What motivates or influences the need for care to be given here, and what forms of recognition do caregivers receive? Victoria Lawson $(2007,7)$ suggests that individual relations of care involve "understanding how difference is socially constructed, and [thus] a critical ethic of care must be coupled with analysis of the structures and institutions that reproduce exclusion, oppression, environmental degradation," and so on. This reminds us of the importance of critically analyzing why these advocates are needed in such spaces. Although many advocates experience what they characterize as transformative experiences in their encounters with asylum-seekers, all recognize that the government should provide the required legal services and strongly agree that asylum-seekers should not be incarcerated, particularly the especially vulnerable, such as children or those with illness or disabilities.

Legal care, as a concept, embodies significant potential for making sense of practices of care in different sorts of human encounters. Legal advocates in these contexts are typically not medical professionals and thus not meant to provide care in the same ways. Yet, as ethnographic observation demonstrates, their work constitutes a form of care, one that sometimes overlaps with bodily care. As they help detainees and asylum-seekers navigate the processual complexities of asylum and the institutional ambiguities of incarceration, legal advocates tend to the many wounds created by such structures. The very notion of legal care affords us the ability to disentangle the intricacies of these environments and interpret the work 
that legal advocates do in them as care work without ignoring the important role that the law plays in their encounters.

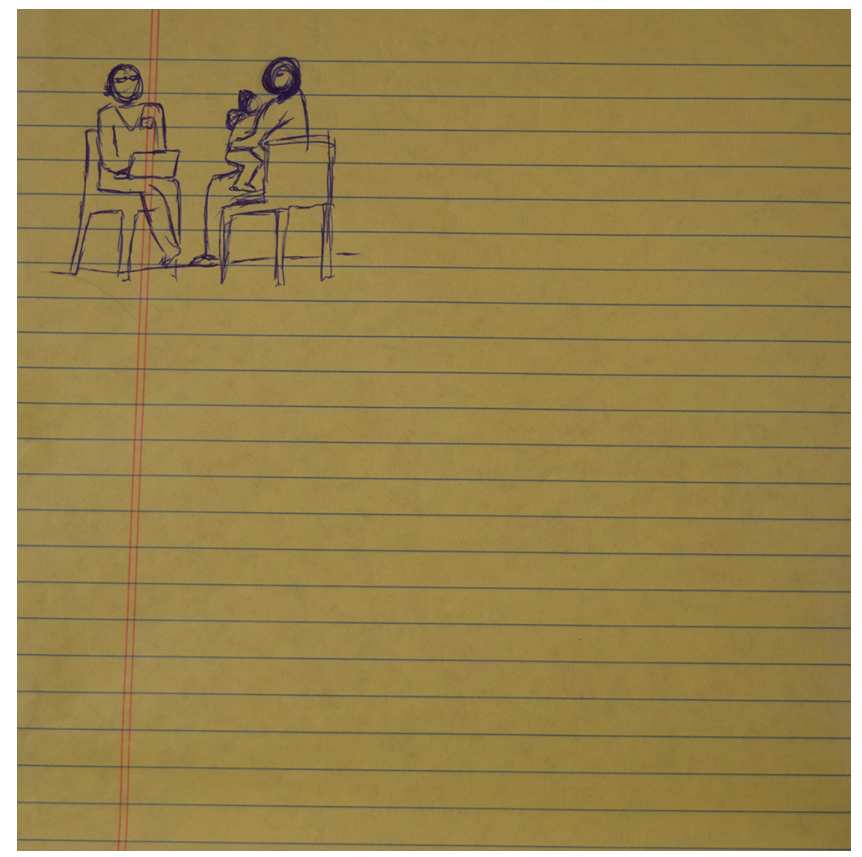

Figure 4. Depiction on a legal pad of an advocate meeting with their client. Drawing by Erin Routon.

\section{CONCLUSIONS}

The frictions surrounding the incidences involving detained children's use of crayons and the ban on hugging in the facility illustrate how figurations of power can be understood more intimately through, or perhaps alongside, care. The right to give care and the ability to receive it, of course, involve expressions of power. In these instances, both the provision and the reception of care are controlled by administrative figures, deployed as means to control and punish legal advocates and detainees. Ultimately, the friction itself results from the existence of legal advocates, as caregivers, in these spaces. It is precisely both their active contestation of what administrators implicitly or explicitly define as care and their attention to the diverse needs of their clients that cause frictions. While administrative authorities repeatedly deploy putative care in ways that reinforce oppressive orders (Ticktin 2011), legal advocates redraw the borders of care through practice to resist. Power is effectively asserted and contested through care. 
Of course, legal advocates recognize the inherent conflict in their existence within these centers, one that hinges, importantly, on some cooperation with the very figures they resist. For despite advocates' legal right to meet with potential clients, administrative authorities wield significant power in allowing or disallowing their continued presence beyond the front doors. Thus one can see how advocates' responses to the conflicts they experienced in detention simultaneously created both traction for their work to continue and barriers for its continuation. "You know, our project struggles, at times, because it has these two kinds of contradictory functions," Carlos, a Dilley project staff member, said as he sat exhausted on the floor of the office room. His stickered laptop and a messy stack of client paperwork rested on his legs. He continued, explaining to a weekly volunteer: "These functions conflict in that one, we have established this working relationship with ICE and CoreCivic, so that we can get the women the help they need so they don't get steamrolled, forgotten, deported, whatever. But then we have this other work that is all about ending family detention. It seems paradoxical to me, because the one sort of hurts the ends of the other." While trying to effect the collapse of the facility's operation, drawing attention to the ways in which these forms of incarceration should not exist, advocates' everyday work involves managing the very mechanisms of the operation. This in itself creates a form of friction, as one goal, ending family detention, grates against another, providing daily legal care to as many detainees as possible.

Much has changed with respect to family detention since I completed my lengthy stay in the field in late 2017. While the modern instantiation of family detention was reinstituted and reconfigured during the Obama administration, the Trump administration effected even greater violence on asylum-seeking families, far beyond what many, even legal advocates, would have predicted. Yet as the years have passed and Americans have observed the countless atrocities visited on migrants and otherwise undocumented groups, one aspect of my field observations has remained relatively unchanged: legal advocates performing as caregivers to those incarcerated in these facilities. It is my ultimate contention that these actors are, and should be recognized as, caregivers. As I have shown, caring for detainees in these spaces is invariably shaped by the frictions and ambiguities that mark the environment and its fleeting encounters. Legal advocates navigate these painful terrains through intimacy and relationality, tinkering with care on uncertain grounds, reconfiguring both power and resistance. 


\section{CODA}

As a final note, it is important to recognize both the effects of the Trump administration on the individuals described in this article, as well as the current state of these environments as the United States has transitioned to a new presidential administration. The past four years of the Trump administration have brought about vast expansions of incarcerations and separations of asylum-seeking migrant families (Flagg and Calderón 2020), new limitations to asylum law, and the institution of new mechanisms to refuse entry, such as the "Remain in Mexico” policy, or Migrant Protection Protocols (MPP). Furthermore, as of late 2020, several hundred children that were separated from their parents at the border, as a result of "zero tolerance" measures, have yet to be reunited with their family members (Pilkington 2020). In March 2021, officials in the Biden administration announced that the two south Texas family detention facilities-Dilley and Karnes — would cease to detain asylum-seeking families. Instead, they explained, the facilities were being rebranded as "reception centers," wherein asylum-seeking families would stay for much shorter periods of time while being tested for COVID-19 and arranging travel to their new homes. The third family facility, in Berks County, Pennsylvania, abruptly released all of its remaining detained families, though the future function of the facility itself, as it has not officially been closed, remains unclear. Some advocates have expressed relief at these changes, as it means that families will not be required to undergo asylum processes while detained in these facilities, sometimes for long periods. Many, however, continue to express their frustrations and skepticism, asking why the facilities must remain open, particularly when local communities and programs are capable of supporting these families with their needs. These advocates point to the fact that while the function and language around these facilities have been reformulated, even in positive ways, they are still, nonetheless, spaces from which asylum-seeking families cannot willingly escape. Activist, filmmaker, and formerly incarcerated Japanese American Dr. Satsuki Ina recently penned an article on the matter, reminding President Biden that whatever you wish to call them, a "cage is still a cage" (Ina 2021). Still, what precisely will transpire with the new administration in the coming years has yet to be seen, but what is already apparent is advocates' continued commitment to asylum-seeking families' care.

\section{ABSTRACT}

The modern instantiation of migrant family detention in the United States has resulted in the creation of carceral spaces in which conflict and care intermingle in 
everyday encounters. While legal advocates traversing these spaces offer critical aid to the detained, asylum-seeking parents and children confined within, legal advocacy is rarely recognized as caregiving work. Drawing from my ethnographic research with voluntary legal advocates working at family detention facilities in South Texas, this article demonstrates the potential for deploying a lens of care to such encounters, which I ultimately frame as "legal care." I argue that cross-disciplinary conceptualizations of care, which emphasize its interdependency, relationality, and contested terrains (Puig de la Bellacasa 2017), as well as its practices as being marked by a continuous tinkering (Mol 2010), offer windows to reconfigurations of care and power that reside amid both the mundane and unpredictable frictions that characterize these environments. [legal advocacy; care; asylum; incarceration; family detention; United States]

\section{NOTES}

Acknowledgments Words cannot properly express my feelings about the legal advocates at the center of this article's story. The individuals who served the projects at these detention facilities were some of the most admirable people I have ever known and had the fortune to work alongside. Family detention legal advocates are infinitely tireless, creative, and, above all, caring individuals engaged in what is objectively heartbreaking work. It was both a pleasure and a pain to observe and assist these caregivers in their work every day in these facilities throughout my dissertation research, from which this article derives. As work with asylum-seekers makes clear, reliving trauma is neither desirable nor easy, and yet, despite that, these advocates consistently and enthusiastically volunteered to recount the entirety of their often painful experiences in family detention in my interviews and conversations with them. I feel lucky to have known them, and I hope that this article serves as an accurate representation of what they shared with me. I would also like to acknowledge my dissertation advisors at Cornell, who provided me with careful advice and support throughout the many years of this research: Drs. Sofia Villenas, Vilma Santiago-Irizarry, and Adam Smith. I also thank my family, especially my partner, Dr. John Gorczyk, for both the emotional support they provided during this research and the many drafts of this article they graciously read. I extend my appreciation to the highly supportive editors and reviewers of Cultural Anthropology for offering thoughtful feedback throughout the publication process. Lastly, while legal advocates stand at the center of this article, this story simultaneously concerns the parents and children imprisoned in these facilities. I am incredibly grateful that they allowed me to play some small part in their lives, doing what I could to help them in their journeys. Memories of their courage, kindness, and resilience remain with me every day, as do their stories of pain and trauma, some of which were written, needlessly, as they crossed the Mexico-United States border.

1. While public discussions of these interviews often simply refer to them as "credible fear" interviews, there are actually two types. Those applicants deemed "subject to administrative removal" or who have had a "prior order of removal" from the United States must undergo a reasonable fear interview. Others who do not have this record will undergo a credible fear interview. Unfortunately and confoundingly, the burden of proof for passing the reasonable fear interview is much higher than for the credible fear interview, putting those who have previous records at an unfair disadvantage in their interview (USCIS 2019).

2. See Reno v. Flores, 507 U.S. 292 (1993), United States Supreme Court, March 23, 1993.

3. Pseudonyms are used for all individuals referenced throughout this article.

4. It should also be noted that despite institutional policies and regulations, evidence has shown that claims of sexual assault in carceral spaces are rarely adjudicated in favor of 
the prisoner. Of course, assault claims are widespread across migrant detention facilities in the United States, including in family detention facilities. This concern was one of the reasons why the Artesia facility - the first modern family center - was ultimately shuttered, advocates claim, and it has continued to plague detainees in other family facilities.

5. While this particular site no longer exists, the legal project in Dilley continues to function.

\section{REFERENCES}

Abel, Richard L.

1995 Politics by Other Means: Law in the Struggle against Apartheid, 1980-1994. New York: Routledge.

Alber, Erdmute, and Heike Drotbohm, eds.

2015 Anthropological Perspectives on Care: Work, Kinship, and the Life-Course. New York: Palgrave Macmillan.

American Immigration Council

2019 “A Primer on Expedited Removal." Washington, D.C.: American Immigration Council. https://www.americanimmigrationcouncil.org/research/primer-expeditedremoval.

Boris, Eileen, and Rhacel Salazer Parreñas, eds.

2010 Intimate Labors: Cultures, Technologies, and the Politics of Care. Stanford, Calif.: Stanford University Press.

Cabot, Heath

2013 "Engagements and Interruptions: Mapping Emotion at an Athenian Asylum Advocacy NGO.” In Ethnographies of Social Support, edited by Markus Schlecker and Friederike Fleischer, 141-59. New York: Palgrave Macmillan.

Comfort, Megan

2008 Doing Time Together: Love and Family in the Shadow of the Prison. Chicago: University of Chicago Press.

Cooper, Jessica

2018 “Trapped: The Limits of Care in California's Mental Health Courts." Social Justice 44, no. 1: 121-41. www.jstor.org/stable/26405740.

CoreCivic

n.d. "South Texas Family Residential Center." Accessed March 23, 2021. https://www. corecivic.com/facilities/south-texas-family-residential-center.

Coutin, Susan Bibler

2000 Legalizing Moves: Salvadoran Immigrants' Struggle for U.S. Residency. Ann Arbor: University of Michigan Press.

2016 Exiled Home: Salvadoran Transnational Youth in the Aftermath of Violence. Durham, N.C.: Duke University Press.

Cunningham, Clark D.

1992 "Lawyer as Translator, Representation as Text: Towards an Ethnography of Legal Discourse." Cornell Law Review 77: 1298-1387. https://scholarship.law.cornell. edu/clr/vol77/iss6/4.

Eagly, Ingrid V., and Steven Shafer

2015 "A National Study of Access to Counsel in Immigration Court." University of Pennsylvania Law Review 164, no. 1: 1-91. https://scholarship.law.upenn.edu/

Fassin, Didier penn_law_review/vol164/iss1/2.

2016 Prison Worlds: An Ethnography of the Carceral Condition. Malden, Mass.: Polity.

Flagg, Anna, and Andrew R. Calderón

2020 “500,000 Kids, 30 Million Hours: Trump's Vast Expansion of Child Detention." Marshall Project, October 30. https://www.themarshallproject. org/2020/10/30/500-000-kids-30-million-hours-trump-s-vast-expansion-ofchild-detention. 
Foucault, Michel

1977 Discipline and Punish: The Birth of the Prison. Translated by Alan Sheridan. New

Garcia, Angela York: Vintage Books.

2010 The Pastoral Clinic: Addiction and Dispossession along the Rio Grande. Berkeley: University of California Press.

Good, Anthony

2006 Anthropology and Expertise in the British Asylum Courts. New York: RoutledgeCavendish.

Gupta, Akhil

2012 Red Tape: Bureaucracy, Structural Violence, and Poverty in India. Durham, N.C.: Duke

Hall, Alexandra University Press.

2012 Border Watch: Cultures of Immigration, Detention and Control. London: Pluto.

Hamington, Maurice

2004 Embodied Care: Jane Addams, Maurice Merleau-Ponty, and Feminist Ethics. Urbana: University of Illinois Press.

Henderson, Lynne

1987 "Legality and Empathy." Michigan Law Review 85, no. 7: 1574-1653.

Hochschild, Arlie Russell

1983 The Managed Heart: Commercialization of Human Feeling. Berkeley: University of California Press.

Hunleth, Jean

2019 “Zambian Children's Imaginal Caring: On Fantasy, Play, and Anticipation in an Epidemic.” Cultural Anthropology 34, no. 2: 155-86. https://doi.org/10.14506/ ca34.2.01.

ICE (Immigration and Customs Enforcement)

n.d. "PREA.” Accessed March 16, 2021. https://www.ice.gov/detain/prea.

Ina, Satsuki

2021 "A Cage Is Still a Cage: President Biden Must End U.S. Detention of Children and Families.” TIME, March 11. https://time.com/5945307/biden-end-detentionmigrant-children/.

James, Deborah, and Evan Killick

2012 "Empathy and Expertise: Case Workers and Immigration/Asylum Applicants in London." Law and Social Inquiry 37, no. 2: 430-55. https://doi.org/10.1111/j.17474469.2012.01312.x.

Kittay, Eva Feder, and Ellen K. Feder, eds.

2002 The Subject of Care: Feminist Perspectives on Dependency. Lanham, Md.: Rowman and Littlefield.

Laughland, Oliver

2016 "US Detention Facility Restricts Use of Crayons for Migrant Children.” Guardian (UK), November 17. https://www.theguardian.com/us-news/2016/nov/17/

Lawson, Victoria migrant-children-crayons-banned-karnes-detention.

2007 "Geographies of Care and Responsibility." Annals of the Association of American Geographers 97, no. 1: 1-11. https://doi.org/10.1111/j.1467-8306.2007.00520.x.

Loyd, Jenna M., and Alison Mountz

2018 Boats, Borders, and Bases: Race, the Cold War, and the Rise of Migration Detention in the United States. Oakland: University of California Press.

Martin, Lauren

2015 "Noncitizen Detention: Spatial Strategies of Migrant Precarity in US Immigration and Border Control." Annales de géographie 702-703: 231-47. https://doi. org/10.3917/ag.702.0231. 
Mattingly, Cheryl

2010 The Paradox of Hope: Journeys through a Clinical Borderland. Berkeley: University of California Press.

Merry, Sally Engle

1990 Getting Justice and Getting Even: Legal Consciousness among Working-Class Americans. Chicago: University of Chicago Press.

2006 Human Rights and Gender Violence: Translating International Law into Local Justice.

Mertz, Elizabeth Chicago: University of Chicago Press.

2007 The Language of Law School: Learning to "Think Like a Lawyer." Oxford: Oxford University Press.

Mol, Annemarie, Ingunn Moser, and Jeannette Pols, eds.

2010 Care in Practice: On Tinkering in Clinics, Homes and Farms. Bielefeld, Germany: Transcript.

Mountz, Alison

2010 Seeking Asylum: Human Smuggling and Bureaucracy at the Border. Minneapolis: University of Minnesota Press.

2012 “Mapping Remote Detention: Dis/location through Isolation." In Beyond Walls and Cages: Prisons, Borders, and Global Crisis, edited by Jenna M. Loyd, Matt Mitchelson, and Andrew Burridge, 91-104. Athens: University of Georgia Press.

Mulla, Sameena

2014 The Violence of Care: Rape Victims, Forensic Nurses, and Sexual Assault Intervention. New York: NYU Press.

Murray, Marjorie, Sofía Bowen, Marisol Verdugo, and Jona Holtmannspötter

2017 "Care and Relatedness among Rural Mapuche Women: Issues of Cariño and Empathy." Ethos 45, no. 3: 367-85. https://doi.org/10.1111/etho.12171.

Pierce, Jennifer L.

1995 Gender Trials: Emotional Lives in Contemporary Law Firms. Berkeley: University of California Press.

Pilkington, Ed

2020 "Parents of 545 Children Still Not Found Three Years after Trump Separation Policy.” Guardian (UK), October 21. https://www.theguardian.com/usnews/2020/oct/21/trump-separation-policy-545-children-parents-still-notfound.

Preston, Julia

2014 "Detention Center Presented as Deterrent to Border Crossings." New York Times, December 15. https://www.nytimes.com/2014/12/16/us/homeland-securitychief-opens-largest-immigration-detention-center-in-us.html.

Puig de la Bellacasa, María

2012 “Nothing comes without its world': Thinking with Care." Sociological Review 60, no. 2: 197-216. https://doi.org/10.1111\%2Fj.1467-954X.2012.02070.x.

2017 Matters of Care: Speculative Ethics in More Than Human Worlds. Minneapolis: University of Minnesota Press.

RAICES T.

n.d. "To: Immigration and Customs Enforcement: End the Crayon Ban at Karnes Family Detention Center.” Mijente. Accessed March 16, 2021. https://action. mijente.net/petitions/end-the-crayon-ban-at-karnes.

Ryo, Emily

2018 "Representing Immigrants: The Role of Lawyers in Immigration Bond Hearings." Law and Society Review 52, no. 2: 503-31. https://doi.org/10.1111/lasr.12328.

Sarat, Austin, and Stuart A. Scheingold, eds.

2005 The Worlds Cause Lawyers Make: Structure and Agency in Legal Practice. Stanford, Calif.: Stanford Law and Politics. 
Scheingold, Stuart A., and Austin Sarat

2004 Something to Believe In: Politics, Professionalism, and Cause Lawyering. Stanford, Calif.: Stanford Law and Politics.

Texas Department of Criminal Justice

n.d. "Briscoe (DB): Correctional Institutions Devision — Prison." Accessed March 16, 2021. https://www.tdcj.texas.gov/unit_directory/db.html.

Ticktin, Miriam

2011 Casualties of Care: Immigration and the Politics of Humanitarianism in France. Berkeley: University of California Press.

Tronto, Joan C.

1993 Moral Boundaries: A Political Argument for an Ethic of Care. New York: Routledge.

Tsing, Anna Lowenhaupt

2005 Friction: An Ethnography of Global Connection. Princeton, N.J.: Princeton University Press.

USCIS (U.S. Citizenship and Immigration Services)

2019 "Affirmative Asylum, Credible Fear, and Reasonable Fear." https://www.uscis. gov/sites/default/files/USCIS/Resources/Resources\%20for\%20Congress/ USCIS_OLIA_March_2019_Hill_Conference_Asylum_Overview.pdf. 